\title{
Article \\ Effects of Electron Beam Irradiation on Acaricide-Resistant and Susceptible Strains of Tetranychus urticae (Acari: Tetranychidae)
}

\author{
Hyun-Na Koo ${ }^{1}$, Jin-Hyun Oh ${ }^{1}$, Jong-Chan Jeon ${ }^{1}$, Won-Jin Kang ${ }^{1}$, Sun-Ran Cho ${ }^{1}$, Yuri Kim ${ }^{2}$ and Gil-Hah Kim ${ }^{1, *}$ \\ 1 Department of Plant Medicine, College of Agriculture, Life and Environment Sciences, Chungbuk National \\ University, Cheongju 28644, Korea; 913029@cbnu.ac.kr (H.-N.K.); wlsgus5@korea.kr (J.-H.O.); \\ chan7475@chungbuk.ac.kr (J.-C.J.); wjkang@dongoh.co.kr (W.-J.K.); wonfight@chungbuk.ac.kr (S.-R.C.) \\ 2 EB Tech Co., Ltd., Daejeon 34028, Korea; yrkim@eb-tech.com \\ * Correspondence: khkim@cbnu.ac.kr; Tel.: +82-43-261-2555
}

check for

updates

Citation: Koo, H.-N.; Oh, J.-H.; Jeon, J.-C.; Kang, W.-J.; Cho, S.-R.; Kim, Y.; Kim, G.-H. Effects of Electron Beam Irradiation on Acaricide-Resistant and Susceptible Strains of Tetranychus urticae (Acari: Tetranychidae). Appl. Sci. 2021, 11, 8116. https://doi.org/ 10.3390/app11178116

Academic Editor:

Spiridon Mantzoukas

Received: 8 July 2021

Accepted: 29 August 2021

Published: 31 August 2021

Publisher's Note: MDPI stays neutral with regard to jurisdictional claims in published maps and institutional affiliations.

Copyright: (c) 2021 by the authors. Licensee MDPI, Basel, Switzerland. This article is an open access article distributed under the terms and conditions of the Creative Commons Attribution (CC BY) license (https:/ / creativecommons.org/licenses/by/ $4.0 /)$.
Simple Summary: A lab-selected strain of the two-spotted spider mite, Tetranychus urticae Koch, exhibited strong resistance to acequinocyl, bifenazate, and etoxazole in comparison with a susceptible strain. This study compared the development and reproduction in acaricide-resistant and -susceptible strains of T. urticae by electron beam irradiation. Both T. urticae strains had similar radiosensitivities and $400 \mathrm{~Gy}$ could be used as a phytosanitary treatment for both strains of this species.

Abstract: The objective of our study was to compare the effects of electron beam irradiation on the development and reproduction of Tetranychus urticae strains that were susceptible or resistant to acequinocyl, bifenazate, and etoxazole. Electron beam irradiation (50-400 Gy) was applied to T. urticae eggs, nymphs, and adults, after which the hatching rate, the emergence rate, longevity, and fecundity were analyzed. Eggs of all the T. urticae strains were irradiated with $150 \mathrm{~Gy}$, and none of them hatched. When protonymphs were irradiated with $300 \mathrm{~Gy}$, oviposition and thus $F_{1}$ hatchability in newly emerged adults were completely suppressed. The $F_{1}$ hatching rate of irradiated adults began to markedly decrease with a dose of $200 \mathrm{~Gy}$, and all strains experienced $100 \%$ inhibition at a dose of $400 \mathrm{~Gy}$. Sodium dodecyl sulfate polyacrylamide gel electrophoresis (Sodium dodecyl sulfate polyacrylamide gel electrophoresis) showed substantial reductions in the levels of a $50 \mathrm{kDa}$ protein in the susceptible and three resistant strains of T. urticae after irradiation with $400 \mathrm{~Gy}$. These results indicate that a dose of $400 \mathrm{~Gy}$ was required to inhibit the normal development and reproduction of $T$. urticae, and susceptible and acaricide-resistant strains of T. urticae had identical radiosensitivities.

Keywords: Tetranychus urticae; acaricide resistance; electron beam

\section{Introduction}

The two-spotted spider mite, Tetranychus urticae, is known as a major pest that causes economic loss in agriculture and floriculture not only in Korea, but also worldwide, because it has a short life cycle and develops rapid resistance to acaricides [1-3]. T. urticae has developed resistance to most acaricides [4]. The resistance of mites has shifted from simple to complex, and cross-resistance has become quite complex [5].

Recently, ionizing radiation has become one of the most common quarantine treatments for insect pests, and it includes gamma-ray, X-ray, and electron beam radiation. Gamma radiation consists of high-energy photons that penetrate living cells and cause ionization. Electron beams and X-rays consist of electromagnetic radiation, ionizing radiation, and photons with energies similar to those of gamma rays. These ionizing radiations produce free radicals in cells when they interact with atoms or molecules. Ionizing radiation is used as a quarantine disinfection method against fruit flies before 10 different types of fruits and 5 types of vegetables are transported from Hawaii to mainland United States and is practically applied in many countries, including Thailand, Mexico, and India [6]. In Korea, ionizing radiation has been used for the disinfection of medical supplies, foods, and 
processed products, and in the semiconductor industry $[7,8]$. However, its active recent applications relate to the control of insect pests. According to the results of a previous study, ionizing radiation treatment causes abnormal development and reproduction rather than an immediate insecticidal effect, leading to infertility [9]. Ionizing radiation has a great advantage as a quarantine treatment method because it has a shorter processing time than fumigation treatment and does not leave behind any residues [10].

In previous studies, the susceptibility of insecticide-resistant insect pests to electron beams was studied with Rhyzopertha dominica [11]. Phosphine $\left(\mathrm{PH}_{3}\right)$-resistant $R$. dominica was more resistant than $\mathrm{PH}_{3}$-susceptible $R$. dominica to electron beam treatment. In other studies, there was no significant difference in the effect of electron beam irradiation between imidacloprid-susceptible and imidacloprid-resistant Aphis gossypii [12]. Therefore, we compared the effects of electron beam irradiation on the development and reproduction of strains of T. urticae that are susceptible or resistant to acequinocyl, bifenazate, and etoxazole. Our studies provide basic data for disinfection using ionizing radiation for floriculture and agricultural quarantine.

\section{Materials and Methods}

\subsection{Test Mites}

The susceptible (S) strain of T. urticae used in this study was established in 2005 in a laboratory at Chungbuk National University (Cheongju, South Korea) and was never exposed to any acaricide. The acequinocyl-resistant (AR) T. urticae population was collected at a rose plantation in Gimhae, Gyungnam, South Korea, in January 2001. The bifenazateresistant (BR) T. urticae population was collected at a rose plantation in Chilgok, Gyungbuk, South Korea, in December 2000. The etoxazole-resistant (ER) T. urticae population was collected at a rose plantation in Buyeo, Chungnam, South Korea, in February 2000. These resistant strains were treated weekly with a range of concentrations corresponding to the $\mathrm{LC}_{30}-\mathrm{LC}_{50}$ values. Commercially formulated acequinocyl (15\% Suspension concentrate), bifenazate $(13.5 \% \mathrm{SC})$, and etoxazole $(10 \% \mathrm{SC})$ were purchased from a farm supply store (Seowon Co., Cheongju, South Korea). Tetranychus urticae were reared at $25-27{ }^{\circ} \mathrm{C}$ in 40-60\% RH under a 16L: 8D photoperiod. Kidney beans (Phaseolus vulgaris L.) were used as the host plants.

\subsection{Preparation and Electron Beam Irradiation of Experimental Mites}

Electron beam irradiation was conducted at EB-Tech Co., Ltd. (Daejeon, South Korea) using a high-energy linear accelerator (UELV10-10S, $10 \mathrm{MeV}$ ). The different developmental stages (eggs, nymphs, and adults) of T. urticae were treated with doses of 0 (control), 50, 100, 150, 200, 300, and $400 \mathrm{~Gy}$. We based our choice of dose on previous studies [13,14]. Alanine pellet dosimeters were measured with a Bruker (ES 200-2106, Billerica, MA, USA). Twenty females of T. urticae adults were placed in a Petri dish $(6.0 \mathrm{~cm}$ in diameter by 1.5 $\mathrm{cm}$ in height) with kidney bean leaf disks ( $3.5 \mathrm{~cm}$ diameter) on cotton wool soaked with water. The females were allowed to lay eggs for $12 \mathrm{~h}$ and were then removed. Twenty protonymphs were placed in a Petri dish under the same conditions used for the eggs. Twenty adult females ( $24 \mathrm{~h}$ after emergence) were placed in a Petri dish. For electron-beamirradiated eggs, the emergence rate of larvae and the longevity and fecundity of emerged adults were recorded. The numbers of adults surviving after 2 days were also counted. For electron-beam-irradiated nymphs, emergence rate, longevity, and fecundity of emerged adults and hatchability of the eggs were recorded. For electron-beam-irradiated adults, longevity and fecundity and hatchability of the eggs were recorded. Data on untreated controls were also recorded. The treatment was repeated three times.

\subsection{SDS-PAGE}

The protein patterns in irradiated and nonirradiated T. urticae were evaluated using sodium dodecyl sulfate-polyacrylamide gel electrophoresis (SDS-PAGE). After $150 \mu \mathrm{L}$ of cell lysis buffer (iNtRON, Seongnam, South Korea) was added to the mites and ho- 
mogenized via sonication, the supernatants were then electrophoresed at $100 \mathrm{~V}$ on a $10 \%$ SDS-PAGE gel. After electrophoresis, the gel was stained with staining solution (100 mg of brilliant blue, $45 \mathrm{~mL}$ of methanol, $10 \mathrm{~mL}$ of glacial acetic acid, and $45 \mathrm{~mL}$ of distilled water) for $4 \mathrm{~h}$ at room temperature and destained with destaining solution $(45 \mathrm{~mL}$ of methanol, $10 \mathrm{~mL}$ of glacial acetic acid, and $45 \mathrm{~mL}$ of distilled water).

\subsection{Data Analysis}

To estimate the parameters of the concentration-mortality line for each leaf-dip bioassay, the replica data were collected and analyzed using the probit model in the SAS program [15]. The $\mathrm{LC}_{50}$ values were considered different at $p<0.01$. The effects of electron beam irradiation on hatchability, emergence rate, adult longevity, fecundity, and $F_{1}$ egg hatching were compared by one-way analysis of variance (ANOVA) or general linear model (GLM). The means were separated by Tukey's test. All statistical analyses were conducted using JMP (ver. 9.0.2; SAS Institute Inc., Cary, NC, USA.).

\section{Results}

\subsection{Resistance Ratio of T. urticae to Acaricides}

The susceptibility of T. urticae adult females to acequinocyl, bifenazate, and etoxazole was evaluated in the S, AR, BR, and ER strains (Table 1). The resistance ratios (RRs) of the AR, BR, and ER strains were $>108.5-,>705.3-$, and $>5,000,000$-fold higher than that of the $S$ strain, respectively.

Table 1. Resistance ratio of T. urticae against three types of acaricides.

\begin{tabular}{cccc}
\hline Acaricide & Strain & LC50 (ppm, 95\% CL $\left.\mathbf{~}^{\mathbf{a}}\right)$ & $\mathbf{R R}^{\mathbf{b}}$ \\
\hline \multirow{2}{*}{ Acequinocyl } & $\mathrm{AR}$ & $>2400$ & $>108.5$ \\
& $\mathrm{~S}$ & $22.0(19.1-25.5)$ & 1.0 \\
\hline \multirow{2}{*}{ Bifenazate } & $\mathrm{BR}$ & $>1340$ & $>705.3$ \\
& $\mathrm{~S}$ & $1.9(1.6-2.3)$ & 1.0 \\
\hline \multirow{2}{*}{ Etoxazole } & $\mathrm{ER}$ & $>5000$ & $>5,000,000$ \\
& $\mathrm{~S}$ & $0.0011(0.0008-0.0014)$ & 1.0 \\
\hline
\end{tabular}

a $\mathrm{CL}$, confidence limit. ${ }^{\mathrm{b}} \mathrm{RR}$, resistance ratio $=\mathrm{LC}_{50}$ of the resistant strain $/ \mathrm{LC}_{50}$ of the susceptible strain.

\subsection{Effect of Electron Beam Irradiation on Eggs}

The effects of electron beam irradiation on the eggs of the susceptible and three resistant strains of $T$. urticae are shown in Table 2. The hatching rate of all strains of $T$. urticae was partially reduced when an electron beam dose of $50 \mathrm{~Gy}$ was used. When the electron beam irradiation dose was $100 \mathrm{~Gy}$, the hatching of the eggs of the susceptible strain of T. urticae was completely $(100 \%)$ inhibited, and the hatching of eggs in the three resistant strains was markedly reduced but not fully inhibited. However, the hatching of all three resistant strains was completely inhibited with an electron beam dose of $150 \mathrm{~Gy}$. The longevity of adults emerging from irradiated eggs tended to decrease at 50 Gy irradiation compared to $0 \mathrm{~Gy}$ in both the resistant and susceptible strains of T. urticae. The number of eggs laid decreased with increasing electron beam doses for the BR, ER, and susceptible strains of T. urticae. However, in the AR strain of T. urticae, the number of eggs laid was higher at $50 \mathrm{~Gy}$ than at $0 \mathrm{~Gy}$ but decreased again at $100 \mathrm{~Gy}$. The $F_{1}$ generation hatching rate for the AR, BR, and $\mathrm{S}$ strains of T. urticae tended to decrease as the electron beam dose increased, but the hatching rate of ER T. urticae was $91.2 \%$ at a 100 Gy dose. The emergence rate tended to decrease as the dose increased for all strains of T. urticae. 
Table 2. Effect of electron beam irradiation on eggs of the AR, BR, ER, and S strains of T. urticae.

\begin{tabular}{|c|c|c|c|c|c|c|}
\hline Dose (Gy) & Strain & $\begin{array}{c}\text { Hatchability } \\
(\%)\end{array}$ & $\begin{array}{c}\text { Adult } \\
\text { Longevity } \\
\text { (Day) }\end{array}$ & $\begin{array}{c}\text { No. of Eggs } \\
\text { (/Total) }\end{array}$ & $\begin{array}{l}\text { Hatchability } \\
\text { (F1, \%) }\end{array}$ & $\begin{array}{c}\text { Emergence } \\
\text { Rate (\%) }\end{array}$ \\
\hline \multirow{4}{*}{150} & AR & $0.0 \pm 0.0 \mathrm{a}^{\mathrm{a}}$ & - & - & - & - \\
\hline & $\mathrm{BR}$ & $0.0 \pm 0.0 \mathrm{a}$ & - & - & - & - \\
\hline & ER & $0.0 \pm 0.0 \mathrm{a}$ & - & - & - & - \\
\hline & $\mathrm{S}$ & $0.0 \pm 0.0 \mathrm{a}$ & - & - & - & - \\
\hline \multirow{4}{*}{100} & AR & $8.8 \pm 11.1 \mathrm{a}$ & $10.9 \pm 3.9 \mathrm{~cd}$ & $29.3 \pm 17.2 \mathrm{abc}$ & $50.5 \pm 20.0 \mathrm{a}$ & $32.5 \pm 4.6 \mathrm{a}$ \\
\hline & $\mathrm{BR}$ & $14.7 \pm 20.4 \mathrm{ab}$ & $4.4 \pm 0.8 \mathrm{abcd}$ & $3.8 \pm 7.1 \mathrm{a}$ & $72.9 \pm 19.2 b$ & - \\
\hline & ER & $14.1 \pm 24.3 \mathrm{ab}$ & $6.0 \pm 1.9 \mathrm{ab}$ & $7.9 \pm 11.1 \mathrm{ab}$ & $91.2 \pm 10.4 \mathrm{bc}$ & - \\
\hline & $\mathrm{S}$ & $0.0 \pm 0.0 \mathrm{a}$ & - & - & - & - \\
\hline \multirow{4}{*}{50} & $\mathrm{AR}$ & $62.2 \pm 35.1 \mathrm{~cd}$ & $6.2 \pm 3.4 \mathrm{abcd}$ & $51.6 \pm 22.5 \mathrm{bc}$ & $88.7 \pm 6.9 \mathrm{bc}$ & $85.6 \pm 20.4 b$ \\
\hline & $\mathrm{BR}$ & $47.0 \pm 40.2 \mathrm{bc}$ & $4.9 \pm 3.0 \mathrm{a}$ & $27.6 \pm 26.2 \mathrm{abc}$ & $92.0 \pm 7.0 \mathrm{c}$ & $85.7 \pm 4.3 \mathrm{~b}$ \\
\hline & ER & $82.6 \pm 13.0 \mathrm{~cd}$ & $3.9 \pm 2.3 \mathrm{abcd}$ & $11.5 \pm 17.6 \mathrm{ab}$ & $93.4 \pm 10.9 c$ & $74.4 \pm 17.6 \mathrm{~b}$ \\
\hline & $\mathrm{S}$ & $93.7 \pm 2.1 \mathrm{~d}$ & $3.6 \pm 1.8 \mathrm{abc}$ & $2.3 \pm 3.1 \mathrm{a}$ & $86.5 \pm 15.9 \mathrm{bc}$ & $80.1 \pm 7.9 \mathrm{~b}$ \\
\hline \multirow{4}{*}{0} & AR & $92.4 \pm 9.1 \mathrm{~d}$ & $8.8 \pm 4.0 \mathrm{bcd}$ & $46.7 \pm 28.8 \mathrm{c}$ & $95.1 \pm 4.1 \mathrm{c}$ & $91.7 \pm 7.0 \mathrm{~b}$ \\
\hline & $\mathrm{BR}$ & $94.6 \pm 3.5 \mathrm{~d}$ & $7.0 \pm 2.9 \mathrm{abcd}$ & $37.8 \pm 30.3 \mathrm{bc}$ & $93.0 \pm 8.8 c$ & $83.5 \pm 4.7 b$ \\
\hline & ER & $87.6 \pm 8.4 \mathrm{~d}$ & $7.4 \pm 2.9 \mathrm{~d}$ & $49.7 \pm 19.4 \mathrm{c}$ & $92.3 \pm 11.3 \mathrm{c}$ & $96.0 \pm 4.6 b$ \\
\hline & $S$ & $93.1 \pm 5.6 \mathrm{~d}$ & $7.8 \pm 2.6 \mathrm{bcd}$ & $44.6 \pm 22.7 c$ & $92.6 \pm 6.7 c$ & $89.1 \pm 18.2 b$ \\
\hline
\end{tabular}

${ }^{a}$ Means followed by the same letter did not differ significantly (Tukey test, $p>0.05$ ). Adapted from Ref. [15].

\subsection{Effect of Electron Beam Irradiation on Nymphs}

The effect of electron beam irradiation on T. urticae nymphs is shown in Table 3. Adult emergence showed a tendency to decrease slightly as the irradiation dose increased in all strains of T. urticae, and even at $400 \mathrm{~Gy}$, the emergence rate was over $70 \%$. At $300 \mathrm{~Gy}$, the AR strain had a statistically lower emergence rate than that of the susceptible strain. The longevity of adults from irradiated nymphs was increased compared to the control group (0 Gy), except for the ER strain at $200 \mathrm{~Gy}$. The number of eggs laid by all strains of T. urticae tended to decrease with increasing electron beams doses. The number of eggs laid by the BR strain of T. urticae was completely inhibited at $300 \mathrm{~Gy}$. The number of eggs laid by the susceptible, AR, and ER strains of T. urticae was zero after a $400 \mathrm{~Gy}$ electron beam dose. The hatching rate of the $F_{1}$ generation began to decrease rapidly at $200 \mathrm{~Gy}$. For the BR strain, the hatching rate was zero at $100 \mathrm{~Gy}$. The hatching rate of all strains of T. urticae was totally suppressed at $300 \mathrm{~Gy}$.

Table 3. Effect of electron beam irradiation on nymphs of the AR, BR, ER, and S strains of T. urticae.

\begin{tabular}{|c|c|c|c|c|c|}
\hline Dose (Gy) & Strain & $\begin{array}{c}\text { Emergence Rate } \\
(\%)\end{array}$ & $\begin{array}{l}\text { Adult Longevity } \\
\text { (Day) }\end{array}$ & $\begin{array}{c}\text { No. of Eggs } \\
\text { (잉otal) }\end{array}$ & Hatchability (F1, \%) \\
\hline \multirow{4}{*}{400} & AR & $71.4 \pm 2.0 \mathrm{a}^{\mathrm{a}}$ & $12.3 \pm 3.8$ abcde & $0.0 \pm 0.0 \mathrm{a}$ & - \\
\hline & $\mathrm{BR}$ & $72.6 \pm 0.7 \mathrm{abc}$ & $9.5 \pm 3.1 \mathrm{abcd}$ & $0.0 \pm 0.0 \mathrm{a}$ & - \\
\hline & ER & $73.2 \pm 2.5 \mathrm{abc}$ & $9.6 \pm 4.7$ abcde & $0.0 \pm 0.0 \mathrm{a}$ & - \\
\hline & $\mathrm{S}$ & $77.1 \pm 1.6$ abcde & $11.7 \pm 5.2$ abcde & $0.0 \pm 0.0 \mathrm{a}$ & - \\
\hline \multirow{4}{*}{300} & AR & $72.2 \pm 1.0 \mathrm{ab}$ & $11.5 \pm 5.9$ abcde & $0.1 \pm 0.3 \mathrm{a}$ & $0.0 \pm 0.0 \mathrm{a}$ \\
\hline & $\mathrm{BR}$ & $75.2 \pm 4.2 \mathrm{abcd}$ & $14.4 \pm 7.8$ bcde & $0.0 \pm 0.0 \mathrm{a}$ & - \\
\hline & ER & $82.1 \pm 3.8$ abcdef & $10.1 \pm 3.6$ abcde & $0.1 \pm 0.3 \mathrm{a}$ & $0.0 \pm 0.0 \mathrm{a}$ \\
\hline & $\mathrm{S}$ & $88.4 \pm 2.0 \mathrm{def}$ & $14.1 \pm 6.5 \mathrm{cde}$ & $1.3 \pm 3.6 \mathrm{a}$ & $0.0 \pm 0.0 \mathrm{a}$ \\
\hline \multirow{4}{*}{200} & $\mathrm{AR}$ & $84.5 \pm 4.3$ abcdef & $14.4 \pm 6.6 \mathrm{de}$ & $3.4 \pm 5.6 \mathrm{ab}$ & $6.4 \pm 11.2 \mathrm{a}$ \\
\hline & $\mathrm{BR}$ & $86.8 \pm 0.7 \mathrm{cdef}$ & $11.9 \pm 7.2$ abcde & $9.3 \pm 9.0 \mathrm{abc}$ & $0.7 \pm 2.2 \mathrm{a}$ \\
\hline & ER & $83.3 \pm 0.6$ abcdef & $9.7 \pm 4.7 \mathrm{abcd}$ & $7.1 \pm 7.6 \mathrm{ab}$ & $0.0 \pm 0.0 \mathrm{a}$ \\
\hline & $\mathrm{S}$ & $84.8 \pm 3.9$ abcdef & $15.5 \pm 7.0 \mathrm{e}$ & $5.5 \pm 5.9 \mathrm{ab}$ & $6.3 \pm 10.8 \mathrm{a}$ \\
\hline
\end{tabular}


Table 3. Cont.

\begin{tabular}{|c|c|c|c|c|c|}
\hline Dose (Gy) & Strain & $\begin{array}{c}\text { Emergence Rate } \\
(\%)\end{array}$ & $\begin{array}{l}\text { Adult Longevity } \\
\text { (Day) }\end{array}$ & $\begin{array}{l}\text { No. of Eggs } \\
\text { (우Total) }\end{array}$ & Hatchability (F1, \%) \\
\hline \multirow{4}{*}{100} & $\mathrm{AR}$ & $84.8 \pm 2.7$ abcdef & $8.8 \pm 3.3$ abcde & $25.1 \pm 19.3 \mathrm{~cd}$ & $57.9 \pm 17.2 \mathrm{bc}$ \\
\hline & $\mathrm{BR}$ & $86.4 \pm 3.1$ bcdef & $8.9 \pm 4.5$ abcde & $5.3 \pm 6.4 \mathrm{ab}$ & $0.0 \pm 0.0 \mathrm{a}$ \\
\hline & ER & $87.8 \pm 4.0 \mathrm{def}$ & $8.9 \pm 4.1$ abcde & $19.5 \pm 10.2 b c$ & $44.8 \pm 23.2 \mathrm{~b}$ \\
\hline & S & $85.7 \pm 6.2$ abcdef & $7.0 \pm 3.3 \mathrm{a}$ & $5.1 \pm 5.2 \mathrm{ab}$ & $81.8 \pm 22.0 \mathrm{~cd}$ \\
\hline \multirow{4}{*}{0} & $\mathrm{AR}$ & $89.9 \pm 5.2 \mathrm{ef}$ & $9.0 \pm 3.1$ abcde & $41.2 \pm 17.2 \mathrm{~d}$ & $92.8 \pm 3.5 \mathrm{~d}$ \\
\hline & $\mathrm{BR}$ & $85.9 \pm 4.4$ bcdef & $8.7 \pm 3.1 \mathrm{abc}$ & $41.1 \pm 23.9 \mathrm{~d}$ & $94.5 \pm 4.8 \mathrm{~d}$ \\
\hline & ER & $93.9 \pm 5.8 \mathrm{f}$ & $9.7 \pm 3.0$ abcde & $37.4 \pm 9.8 \mathrm{~d}$ & $96.9 \pm 2.9 \mathrm{~d}$ \\
\hline & $S$ & $88.4 \pm 4.2 \mathrm{def}$ & $8.4 \pm 1.8 \mathrm{ab}$ & $41.4 \pm 19.1 \mathrm{~d}$ & $91.3 \pm 8.7 \mathrm{~d}$ \\
\hline
\end{tabular}

${ }^{a}$ Means followed by the same letter did not differ significantly (Tukey test, $p>0.05$ ). Adapted from Ref. [15].

\subsection{Effect of Electron Beam Irradiation on Adults}

The effect of electron beam irradiation on T. urticae adults is shown in Table 4. Electron beam irradiation had no significant effect on adult longevity in all strains of T. urticae. With 400 Gy irradiation, egg laying was not completely inhibited, but hatching was not successful. At $300 \mathrm{~Gy}$, all strains spawned, but the ER and AR strains did not hatch.

Table 4. Effect of electron beam irradiation on adults of the AR, BR, ER, and S strains of T. urticae.

\begin{tabular}{|c|c|c|c|c|}
\hline Dose (Gy) & Strain & $\begin{array}{c}\text { Adult } \\
\text { Longevity (Day) }\end{array}$ & $\begin{array}{l}\text { No. of Eggs } \\
\text { (ㅇ/Total) }\end{array}$ & $\begin{array}{c}\text { Hatchability } \\
\left(F_{1}, \%\right)\end{array}$ \\
\hline \multirow{4}{*}{400} & $\mathrm{AR}$ & $9.9 \pm 4.2 \mathrm{ab}^{\mathrm{a}}$ & $25.3 \pm 7.6 \mathrm{abc}$ & $0.0 \pm 0.0 \mathrm{a}$ \\
\hline & $\mathrm{BR}$ & $9.9 \pm 4.6 \mathrm{ab}$ & $23.7 \pm 7.6 \mathrm{ab}$ & $0.0 \pm 0.0 \mathrm{a}$ \\
\hline & ER & $7.7 \pm 3.4 \mathrm{ab}$ & $26.0 \pm 13.8 \mathrm{abc}$ & $0.0 \pm 0.0 \mathrm{a}$ \\
\hline & $S$ & $9.3 \pm 4.8 \mathrm{ab}$ & $27.9 \pm 3.4 \mathrm{abc}$ & $0.0 \pm 0.0 \mathrm{a}$ \\
\hline \multirow{4}{*}{300} & $\mathrm{AR}$ & $40.3 \pm 4.3 b$ & $25.6 \pm 10.7 \mathrm{abc}$ & $0.0 \pm 0.0 \mathrm{a}$ \\
\hline & $\mathrm{BR}$ & $8.3 \pm 3.9 \mathrm{ab}$ & $21.3 \pm 5.8 \mathrm{a}$ & $0.7 \pm 2.6 \mathrm{a}$ \\
\hline & ER & $7.5 \pm 2.3 \mathrm{ab}$ & $23.2 \pm 7.6 \mathrm{abc}$ & $0.0 \pm 0.0 \mathrm{a}$ \\
\hline & $\mathrm{S}$ & $7.3 \pm 1.8 \mathrm{ab}$ & $33.5 \pm 10.6 \mathrm{abc}$ & $7.8 \pm 4.0 \mathrm{a}$ \\
\hline \multirow{4}{*}{200} & $\mathrm{AR}$ & $9.5 \pm 4.8 \mathrm{ab}$ & $27.8 \pm 12 \mathrm{abc}$ & $1.5 \pm 3.1 \mathrm{a}$ \\
\hline & $\mathrm{BR}$ & $9.4 \pm 4.4 \mathrm{ab}$ & $35.8 \pm 11.8 \mathrm{abc}$ & $7.5 \pm 11.3 \mathrm{a}$ \\
\hline & ER & $7.5 \pm 1.5 \mathrm{ab}$ & $23.8 \pm 8.9 \mathrm{ab}$ & $1.5 \pm 2.2 \mathrm{a}$ \\
\hline & $\mathrm{S}$ & $6.7 \pm 2.0 \mathrm{a}$ & $28.4 \pm 7.9 \mathrm{abc}$ & $0.2 \pm 0.7 \mathrm{a}$ \\
\hline \multirow{4}{*}{100} & $\mathrm{AR}$ & $8.3 \pm 3.7 \mathrm{ab}$ & $41.5 \pm 25.4 b c$ & $50.3 \pm 32.8 b$ \\
\hline & $\mathrm{BR}$ & $9.1 \pm 4.4 \mathrm{ab}$ & $39.0 \pm 16.4 \mathrm{abc}$ & $49.4 \pm 18.7 \mathrm{~b}$ \\
\hline & ER & $6.9 \pm 1.3 \mathrm{a}$ & $27.0 \pm 13.9 \mathrm{abc}$ & $54.6 \pm 28.5 b$ \\
\hline & S & $6.8 \pm 2.0 \mathrm{a}$ & $29.2 \pm 8.0 \mathrm{abc}$ & $73.1 \pm 7.7 c$ \\
\hline \multirow{4}{*}{0} & AR & $8.2 \pm 1.8 \mathrm{ab}$ & $36.6 \pm 14.9 \mathrm{abc}$ & $88.0 \pm 10.9 \mathrm{~cd}$ \\
\hline & $\mathrm{BR}$ & $8.5 \pm 2.8 \mathrm{ab}$ & $43.8 \pm 17.3 c$ & $91.9 \pm 4.9 \mathrm{~d}$ \\
\hline & ER & $8.5 \pm 3.4 \mathrm{ab}$ & $30.5 \pm 18.0 \mathrm{abc}$ & $86.9 \pm 11 \mathrm{~cd}$ \\
\hline & $S$ & $8.2 \pm 3.5 \mathrm{ab}$ & $32.1 \pm 9.6 \mathrm{abc}$ & $97.9 \pm 2.3 \mathrm{~d}$ \\
\hline
\end{tabular}

a Means followed by the same letter did not differ significantly (Tukey test, $p>0.05$ ). Adapted from Ref. [15].

\subsection{Changes in Protein Synthesis Caused by Electron Beam Irradiation}

We investigated the effect of electron beam irradiation on the changes in protein synthesis of adults of the $S$ and resistant strains of T. urticae. SDS-PAGE analysis of all strains irradiated with an electron beam dose of $400 \mathrm{~Gy}$ indicated that the amount of the protein at approximately $50 \mathrm{kDa}$ was reduced (Figure 1). However, there was no difference between resistant and S strains of T. urticae. In addition, no obvious changes in the levels of proteins of other sizes were detected. 


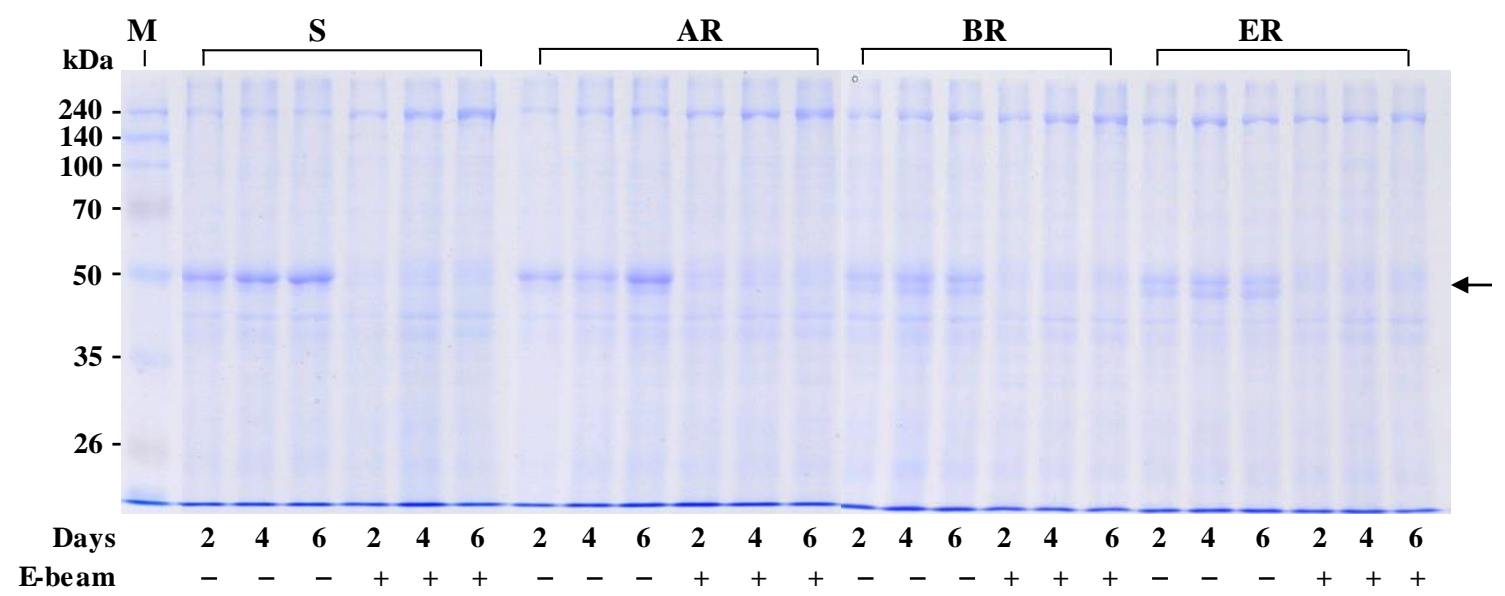

Figure 1. Changes in the expression of T. urticae proteins induced by electron beam irradiation. Protein was harvested from the S, AR, BR, and ER strains at 2, 4, and 6 days after electron beam irradiation (400 Gy) and analyzed by $10 \%$ SDS-PAGE. M, protein size marker; S, susceptible strain; AR, acequinocyl-resistant strain; BR, bifenazate-resistant strain; ER, etoxazole-resistant strain.

\section{Discussion}

Based on this study, we confirmed that electron beam irradiation almost equally inhibits the normal development and reproduction in acaricide-resistant and susceptible strains of two-spotted mites. Tetranychus urticae is usually controlled by pesticides and exhibits a characteristic resistance associated with its short life cycle. In this study, we investigated the effect of electron beam irradiation on the egg, protonymph, and adult stages of T. urticae strains with 100-, 700-, and 5,000,000-fold greater resistance than the susceptible strain to acequinocyl, bifenazate and etoxazole, respectively. It has been reported that even though the electron beam is less penetrative than gamma rays, it can effectively control insect pests and prevent decay when used on cereals, nuts, spices, dried vegetables, tea leaves, and a few types of germinating seeds [16,17]. A previous study also reported that insect pests resistant to insecticides exhibit resistance to ionizing radiation. According to Hasan et al. [11], R. dominica exhibiting resistance to a phosphine fumigant was more highly resistant to electron beams and gamma rays than the susceptible strains of $R$. dominica. Another study showed that phosphine-resistant strains of Tribolium castaneum (Herbst) (Coleoptera: Tenebrionidae) were more tolerant to gamma rays compared with a susceptible strain [18]. Phosphine induces the formation of reactive oxygen radicals, which also generate other radical species [19]. It has been reported that phosphine-resistant insects with mechanisms to prevent oxidative damage also exhibit resistance to electron beams. Therefore, in this study, we investigated whether acaricide-resistant T. urticae also exhibited resistance to electron beam irradiation. As a result, there were some differences between the resistant and susceptible strains of T. urticae, but these did not significantly affect the overall conclusion. The hatching rate of eggs of all strains of T. urticae decreased with increasing electron beam irradiation dose. Hatching was suppressed completely at $150 \mathrm{~Gy}$. The number of eggs laid by adults (successfully hatched) of BR, ER, and S strains of T. urticae decreased as the irradiation dose increased; however, when the AR strain was irradiated with $50 \mathrm{~Gy}$, the number of eggs increased and then decreased again at $100 \mathrm{~Gy}$, suggesting a resurgence of the insect pests. We confirmed that the emergence of adults from irradiated nymphs was not significantly affected by electron beam irradiation except for the AR strain at $300 \mathrm{~Gy}$. In addition, at $200 \mathrm{~Gy}$, the longevity of the ER strains decreased significantly, but there was no significant difference in the other groups. Although significant results were obtained for each group, the goal of our study was to determine whether acaricide-resistant mites were also resistant to electron beam irradiation. From this point of view, there were no significant results overall. In our previous study results, there was no effect of electron beam irradiation on the susceptible and insecticide-resistant cotton aphids [20]. 
Since electron beam irradiation induces abnormal reproduction and development in insect pests depending on the insect species and stage of development, a large amount of basic data is required for ionizing radiation to be utilized for quarantine disinfection. In a previous study, many researchers reported the effects of gamma-ray, X-ray, and electron beam irradiation on Plutella xylostella (Linnaeus) (Lepidoptera: Plutellidae), Myzus persicae (Sulzer) (Hemiptera: Aphididae), Bemisia tabaci (Gennadius) (Hemiptera: Aleyrodidae), Liriomyza trifolii (Burgess) (Diptera: Agromyzidae), Spodoptera litura (F.) (Lepidoptera: Noctuidae), Frankliniella intonsa (Trybom) (Thysanoptera: Thripidae), Drosophila suzukii (Matsumura) (Diptera: Drosophilidae), and Helicoverpa armigera Hübner (Lepidoptera: Noctuidae) [12-14,21-28]. In addition, intracellular DNA was also damaged by ionizing irradiation $[19,20,28]$. Because of this principle, low-dose irradiation has been used in the sterile insect technique (SIT) [29-31].

High-dose electron beam irradiation may result in faster lethal effects than low-dose irradiation and may induce phytotoxicity. Consequently, it is important to provide the optimal dose to induce abnormal development and reproduction (or infertility) in insect pests without causing any phytotoxicity when using electron beams for disinfection of agricultural products and flowers. It is also necessary to find the most resistant stage of development. Among the developmental stages of two-spotted mites, the most resistant stage to electron beams is the adult. Therefore, a dose of $100 \mathrm{~Gy}$ that is effective for eggs cannot control T. urticae adults. The International Atomic Energy Agency (IAEA) provides recommended doses to users based on these basic data.

Electron beam irradiation is an environmentally friendly, chemical-free alternative method that is increasing in use for the disinfestation of insect pests. There are no radioactive sources needed, so there are no security, transportation, or disposal concerns. It has a faster dose rate than gamma rays, so there is a reduced risk of product damage. Electron beam irradiation provides quick-turn terminal sterilization with simple on/off technology. However, so far, ionizing irradiation for quarantine disinfection treatment, it is possible only if the other country permits it.

When investigating the differences in protein synthesis of the adult female T. urticae irradiated with $400 \mathrm{~Gy}$, we confirmed that the level of a $50 \mathrm{kDa}$ protein was markedly reduced in both the susceptible and resistant strains. The levels of proteins of different sizes did not show significant changes with electron beam dose, and no significant differences in the protein profiles of the resistant and susceptible strains were detected following electron beam irradiation. The identification of the $50 \mathrm{kDa}$ protein should be analyzed in further studies using matrix-assisted laser desorption ionization-time of flight .

Therefore, by inhibiting the normal development and reproduction of both susceptible and acaricide-resistant strains, 400 Gy electron beam irradiation seems to be useful for quarantine disinfection of T. urticae. In the future, it is necessary to investigate the differences between acaricide-resistant and susceptible strains by studying their molecular mechanisms of protein synthesis and enzyme activity.

Author Contributions: Conceptualization, H.-N.K. and G.-H.K.; methodology, H.-N.K.; software, S.-R.C.; validation, Y.K.; formal analysis, W.-J.K.; investigation, J.-H.O. and J.-C.J.; data curation, H.-N.K.; writing-original draft preparation, H.-N.K. and J.-H.O.; writing-review and editing, G.-H.K.; supervision, G.-H.K.; funding acquisition, G.-H.K. All authors have read and agreed to the published version of the manuscript.

Funding: This study was supported by a grant from the Korea Atomic Energy Research Institute and the Animal and Plant Quarantine Agency in South Korea.

Institutional Review Board Statement: Not applicable.

Informed Consent Statement: Not applicable.

Data Availability Statement: The data presented in this study are available on request from the corresponding author.

Conflicts of Interest: The authors declare no conflict of interest. 


\section{References}

1. Asada, M. Genetics and biochemical mechanisms of acaricide resistance in phytophagous mights. J. Pestic. Sci. 1978, 3, 61-68. [CrossRef]

2. Takafuji, A.; Ozawa, A.; Nemoto, H.; Gotoh, T. Spider mites of Japan: Their biology and control. Exp. Appl. Acarol. 2000, 24, 319-335. [CrossRef]

3. Lee, Y.S.; Song, M.H.; Ahn, K.S.; Lee, K.Y.; Kim, J.W.; Kim, G.H. Monitoring of acaricide resistance in two-spotted spider mite (Tetranychus urticae) populations from Rose Greenhouses in Korea. J. Asia-Pac. Entomol. 2003, 6, 91-96. [CrossRef]

4. Whalon, M.E.; Mota-Sanchez, D.; Hollingworth, R.M.; Duynslager, L. Arthropod Pesticide Resistance Database. Available online: http:/ / www.pesticideresistance.org (accessed on 21 January 2009).

5. Kim, G.H.; Song, C.; Park, N.J.; Cho, K.Y. Inheritance if resistance in dicofol-selected strain of the two-spotted spider mite, Tetranychus urticae Koch (Acarina: Tetranychidae), and its cross resostance. Korean J. Appl. Entomol. 1994, 33, $230-236$.

6. Follett, P.A. Irradiation to control insects in fruits and vegetables for export from Hawaii. Radiat. Phys. Chem. 2004, 71, 163-166. [CrossRef]

7. Park, J.H.; Lee, J.M.; Lee, S.C. Effect of electron-beam irradiation on the characteristics of green tea (Camellia sinensis L.). J. Korean Soc. Food Sci. Nutr. 2006, 35, 774-779. [CrossRef]

8. Moon, S.R.; Son, B.K.; Yang, J.O.; Woo, J.S.; Yoon, C.M.; Kim, G.H. Effect of electron-beam irradiation on development and reproduction of Bemisia tabaci, Myzus persicae, Plutella xylostella and Tetranychus urticae. Korean J. Appl. Entomol. 2010, 49, 129-137. [CrossRef]

9. Barkai-Golan, R.; Follett, P.A. Irradiation for Quality Improvement, Microbial Safety and Phytosanitation of Fresh Produce; Academic Press: San Diego, CA, USA, 2017.

10. Osouli, S.; Ziaie, F.; Irani Nejad, K.H.; Moghaddam, M. Application of gamma irradiation on eggs, active and quiescence stages of Tetranychus urticae Koch as a quarantine treatment of cut flowers. Radiat. Phys. Chem. 2013, 90, 111-119. [CrossRef]

11. Hasan, M.M.; Todoriki, S.; Miyanoshita, A.; Imamura, T.; Hayashi, T. Soft-electron beam and gamma-radiation sensitivity and DNA damage in phosphine-resistant and -susceptible strains of Rhyzopertha dominica. J. Econ. Entomol. 2006, 99, $1912-1919$. [CrossRef]

12. Yun, S.H.; Koo, H.N.; Kim, H.K.; Cho, S.; Kim, G.H. Effects of electron beam irradiation on six insect pests in different sections of flower boxes for export. J. Asia-Pac. Entomol. 2015, 18, 629-636. [CrossRef]

13. Koo, H.N.; Yun, S.H.; Yoon, C.; Kim, G.H. Electron beam irradiation induces abnormal development and the stabilization of p53 protein of American serpentine leafminer, Liriomyza trifolii (Burgess). Radiat. Phys. Chem. 2012, 81, 86-92. [CrossRef]

14. Yun, S.H.; Lee, S.W.; Koo, H.N.; Kim, G.H. Assessment of electron beam-induced abnormal development and DNA damage in Spodoptera litura (F.) (Lepidoptera: Noctuidae). Radiat. Phys. Chem. 2014, 96, 44-49. [CrossRef]

15. SAS Institute. SAS/STAT User's Guide: Statistics, Version 9.1; SAS Institute: Cary, NC, USA, 2003.

16. Hayashi, T.; Todoriki, S.S. Low energy electron irradiation of food for microbial control. In Irradiation for Food Safety and Quality; Loaharanu, P., Thomas, P., Eds.; Technomic Publishing: Lancaster, PA, USA, 2001; pp. 118-128.

17. Todoriki, S.; Kikuchi, O.K.; Nakaoka, M.; Miike, M.; Hayashi, T. Soft electron (low energy electron) processing of foods for microbial control. Radiat. Phys. Chem. 2002, 63, 349-351. [CrossRef]

18. Nakakita, H.; Hayashi, T.; Aoki, S.; Kawashima, K. Radiosensitivity of phosphine-resistant and susceptible strains of the Bour beetle, Tribolium castaneum (Herbst) (Coleoptera: Tenebrionidae). Jpn. J. Appl. Entomol. Zool. 1985, 29, 242-246. [CrossRef]

19. Hsu, C.H.; Chi, B.C.; Liu, M.Y.; Li, J.H.; Chen, C.J.; Chen, R.Y. Phosphine-induced oxidative damage in rats: Role of glutathione. Toxicology 2002, 179, 1-8. [CrossRef]

20. Yun, S.H.; Koo, H.N.; Lee, S.W.; Kim, H.K.; Kim, Y.; Han, B.; Kim, G.H. A comparative study on the effects of electron beam irradiation on imidacloprid-resistant and-susceptible Aphis gossypii (Hemiptera: Aphididae). Radiat. Phys. Chem. 2015, 112, 151-157. [CrossRef]

21. Koo, H.N.; Yoon, S.H.; Shin, Y.H.; Yoon, C.; Woo, J.S.; Kim, G.H. Effect of electron beam irradiation on developmental stages of Plutella xylostella (Lepidoptera: Plutellidae). J. Asia-Pac. Entomol. 2011, 14, 243-247. [CrossRef]

22. Koo, H.N.; Yun, S.H.; Kim, H.J.; Kim, H.K.; Kim, G.H. X-ray irradiation control of Frankliniella occidentalis and Frankliniella intonsa (Thysanoptera: Thripidae) in the exportation of freshly cut lily flowers. J. Econ. Entomol. 2017, 110, 416-420. [CrossRef]

23. Koo, H.N.; Yun, S.H.; Kim, H.; Kim, G.H. Elucidation of molecular expression associated with abnormal development and sterility caused by electron beam irradiation in Spodoptera litura (F.) (Lepidoptera: Noctuidae). Int. J. Radiat. Biol. 2019, 95, 360-367. [CrossRef]

24. Yun, S.H.; Koo, H.N.; Kim, H.K.; Yang, J.O.; Kim, G.H. X-ray irradiation as a quarantine treatment for the control of six insect pests in cut flower boxes. J. Asia-Pac. Entomol. 2016, 19, 31-38. [CrossRef]

25. Cho, S.R.; Kim, M.; Shin, E.; Kim, H.K.; Koo, H.N.; Kim, G.H. X-ray irradiation-induced abnormal development and DNA damage in Phthorimaea operculella (Lepidoptera: Gelechiidae). Appl. Sci. 2021, 11, 5068. [CrossRef]

26. Kim, J.H.; Kim, J.M.; Park, C.G. X-ray radiation and developmental inhibition of Drosophila suzukii (Matsumura) (Diptera: Drosophilidae). Int. J. Radiat. Biol. 2016, 92, 849-854. [CrossRef] [PubMed]

27. Kim, J.; Jung, S.O.; Jang, S.A.; Kim, J.; Park, C.G. X-ray radiation and development inhibition of Helicoverpa armigera Hübner (Lepidoptera: Noctuidae). Radiat. Phys. Chem. 2015, 115, 148-152. [CrossRef] 
28. Kim, J.; Chung, S.O.; Jang, M.; Jang, S.A.; Park, C.G. Developmental inhibition and DNA damage of Helicoverpa armigera Hübner (Lepidoptera: Noctuidae) by gamma radiation. Int. J. Radiat. Biol. 2015, 91, 827-832. [CrossRef]

29. Bakri, A.; Mehta, K.; Lance, D.R. Sterilizing insects with ionizing radiation. In Sterile Insect Technique. Principles and Practice in Areawide Integrated Pest Management; Dyck, V.A., Hendrichs, J., Robinson, A.S., Eds.; Springer: Dordrecht, The Netherlands, 2005; pp. 233-268.

30. Bakri, A.; Heather, N.; Hendrichs, J.; Ferris, I. Fifty years of radiation biology in entomology: Lessons learned from IDIDAS. Ann. Entomol. Soc. Am. 2005, 98, 1-12. [CrossRef]

31. Bloem, K.A.; Bloem, S.; Carpenter, J. Impact of moth suppression/eradication programmes using the sterile insect technique or inherited sterility. In Sterile Insect Technique. Principles and Practice in Areawide Integrated Pest Management; Dyck, V.A., Hendrichs, J., Robinson, A.S., Eds.; Springer: Dordrecht, The Netherlands, 2005; pp. 677-700. 